\title{
Upaya Pendidikan Islam pada Masa Awal Nabi Muhammad SAW
}

\author{
LINA MAYASARI SIREGAR \\ Sekolah Tinggi Agama Islam Barumun Raya (STIBR) Sibuhuan \\ Jln. Kihajar Dewantara, No. 66 Kab. Padanglawas Kode Pos 22763 \\ e-mail: linamayasarisiregar@yahoo.co.id
}

\begin{abstract}
Abstrak: Pendidikan Islam adalah pendidikan yang didasarkan atas ajaran Islam itu sendiri. Al-Qur'an dan sunnah menjadi pedoman utama dalam pelaksanaan operasionalnya. Di era sekarang, pendidikan Islam terus berupaya untuk meningkatkan kualitas, sehingga segala upaya dilakukan. Salah satu upaya itu misalnya mengkaji ulang dengan analisis yang tajam tentang bagaimana pendidikan Islam yang Nabi Muhammad SAW terapkan pada awal sejarah Islam itu sendiri. Dengan pengkajian terhadap sejarah awal Islam ini diharapkan dapat menyegarkan kembali ingatan kita tentang bagaimana sosok Nabi Muhammad SAW sehingga dapat berhasil membentuk dan membina manusia yang sebelumnya telah mengalami krisis diberbagai lini kehidupan. Berdasarkan kajian yang telah diTernyata Nabi Muhammad mampu mengangkat harkat martabat mereka bahkan mereka menjadi pabrik ilmu dan kebudayaan sekitar kurang lebih enam abad lamanya.
\end{abstract}

Kata Kunci: Upaya, Pendidikan Islam, Muhammad SAW

\section{PENDAHULUAN}

Nabi Muhammad lahir pada hari Senin, 12 Rabiul Awwal 571 M dari pasangan suami isteri yakni Abdullah dan Aminah. Muhammad dilahirkan dari kalangan suku Quraisy, sebuah suku terhormat dari keturunan Ismailiyah. Salah satu keturunan Ismail terdapat seorang yang berkuasa bernama Fhir yang nama lainnya adalah Quraisy. Pada abad kelima masehi, salah seorang keturunan Quraisy yang bernama Qusay berhasil menyatukan suku-suku Quraisy yang bertempat tinggal di Hijaj dan menjadi penguasa Ka'bah (Ali, 2003, 35). Selanjutnya Qusay memiliki beberapa anak yang salah satunya adalah Abdul Manaf, dan Abdul Manaf punya keturunan yaitu Abdus Syam dan Hasyim, dan dari mereka inilah cikal bakal Bani Hasyim dan Bani Umayyah sebagaimana yang dikenal dalam sejarah Islam. Kemudian Muhammad SAW memiliki garis keturunan dari Hasyim bin Abdul Manaf. 


\section{Gambar 1 \\ Silsilah Garis Keturunan Hasyim bin Abdul Manaf}

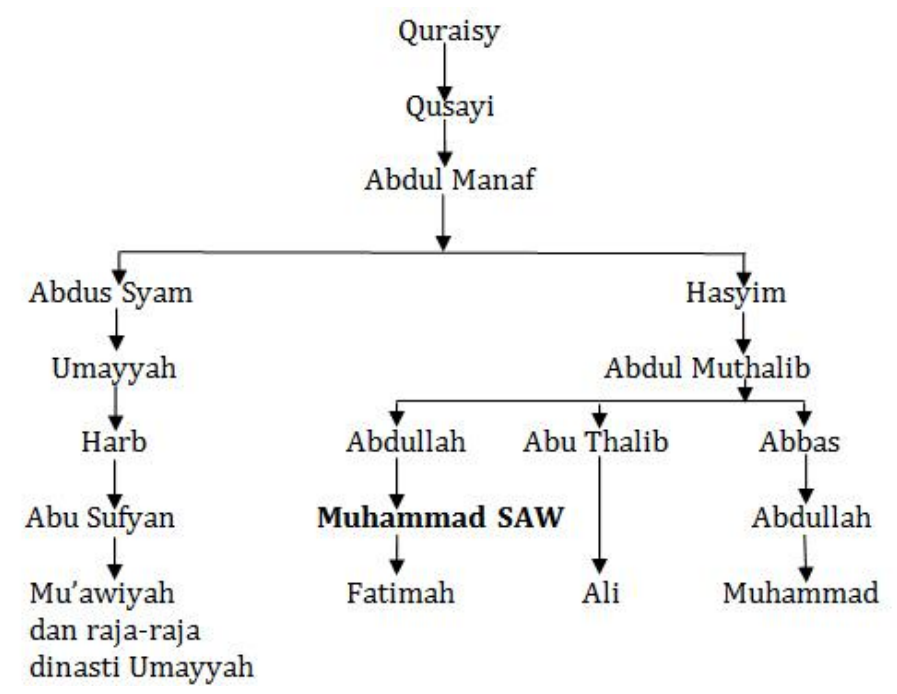

Masa-masa awal (kecil) Muḥammad tidak begitu banyak diketahui, sebagaimana dikemukakan Hitti (2008: 140), namun dalam berbagai riwayat dijelaskan bahwa Muhammad lahir dalam keadaan yatim, artinya dia terlahir sesudah ayahnya meninggal waktu perjalanan pulang dari Syiria akibat menderita sakit.

Adapun nama Muḥammad yang bermakna "yang terpuji" itu disandang beliau merupakan pemberian dari kakeknya Abdul Muthalib, sementara Ahmad merupakan pemberian dari ibunya, sementara al-Amīn yang bermakna "yang terpercaya" merupakan julukan yang diberikan oleh bangsa Quraisy, sehingga dalam perjalanan sejarah Islam ketiga nama ini disandarkan kepada Muḥammad, namun nama yang terus ia sandang dan populer dikalangan masyarakat adalah "Muḥ ammad".

Sesuai dengan adat kebiasaan orang Arab, Aminah menyerahkan Muhammad kepada Halimah untuk dipelihara atau istilah yang sering disebutkan "disusui". Halimah ini berasal dari Bani Sa'id dan Muḥammad hidup dalam pengawasannya selama lima tahun. Kemudian umur enam tahun ia diserahkan kepada ibunya kembali. Tidak lama kemudian ibunya meninggal dan dimakamkan di Abwa, karena jatuh sakit ketika mereka berziarah ke makam Abdullah. Oleh karena itu, ia diasuh oleh kakeknya 'Abdul Muthalib, dan setelah kakeknya meninggal, kewajiban untuk memelihara dan menjaga Muḥammad diserahkan kepada pamannya, Abu Thalib.

Diriwayatkan bahwa ketika pada usia dua belas tahun, Muḥammad menemani pamannya pergi berdagang ke Syiria. Dalam perjalanan mereka bertemu dengan seorang pendeta yang bernama Bahira, dan dia meyakini bahwa Muhammad adalah calon Rasul terakhir (Ali, 2003: 41-42). Maka pendeta itu menyampaikan pesan kepada Abu Thalib untuk menjaga Muhammad dengan baik karena dikhawatirkan orang-orang Yahudi yang mengetahui ciri-ciri kerasulan pada diri Muḥammad akan berbuat jahat terhadapnya (Yatim, 2004: 17).

Begitulah kehidupan Muhammad, sehingga dalam usia mudanya namanya telah dikenal di seluruh pelosok semenanjung Arabia, dengan kepiawaiannya mengembala dan 
berdagang Muḥammad terbentuk menjadi sosok yang mandiri dan bertanggung jawab. Dalam usia kedua puluh lima tahun ia pun bernegosiasi dengan seorang perempuan janda yang bernama Khadijah untuk menjalankan misi dagang, yang akhirnya ia pun menyepakatinya. Dalam aktivitas ini ternyata ia mendapatkan laba karena kejujuran dan kemuliaan yang ada pada dirinya. Perjalanan hidup Muhammad mulai memasuki tahap sejarah pada masa ini, terutama ketika ia menikahi Khadijah sosok seorang perempuan yang memiliki kekayaan, kepribadian kuat dan berwawasan luas.

Pernikahan Muhammad dan Khadijah berlalu dengan tentram, dan mereka adalah pasangan yang bahagia dan harmonis. Khadijah sangat menghargai kecerdasan dan kepemimpinan Muḥammad. Ketika dalam kesedihan, Khadijah tidak pernah lupa menghibur dan membesarkan hati Muḥammad. Hal ini dapat dibuktikan sebagaimana pernyataan beliau "ketika tidak ada seorang pun mempercayai, Khadijahlah satu-satunya orang yang mempercayai, dan ketika orang mengabaikan, Khadijahlah yang selalu menaruh perhatian" (Ali, 2003: 44). Maka pantaslah ketika Khadijah meninggal beliau benar-benar sedih dan merasa kehilangan.

Perkawinan Muḥammad dan Khadijah ini dikarunai sejumlah anak, namun mereka meninggal dalam usia yang masih kanak-kanak kecuali seorang putri yang bernama Fatimah. Dari Fatimah inilah di ketahui peristiwa-peristiwa besar dalam sejarah kehidupan Nabi Muḥammad SAW.

Muḥammad SAW menerima risalah kenabian tepatnya usia 40 tahun. Dimana sebelumnya ia sering mengasingkan diri dan merenung di gua kecil (ghāar) di bukit Hira (Gua Hira) yang terletak di luar kota Mekah (Hitti, 2008: 140). Di dalam gua ini ia mendengar sebuah seruan tepatnya pada tanggal 17 Ramadhan tahun 611 M (Yatim, 2004: 18), yang intinya:
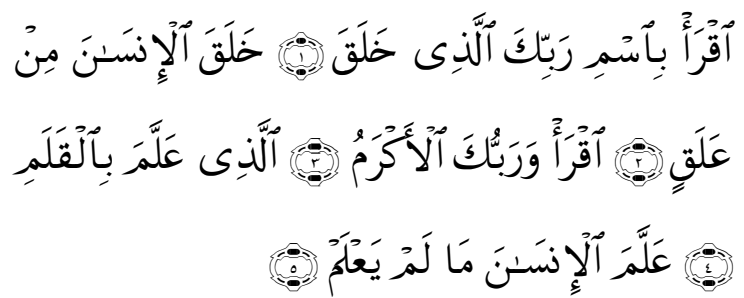

Artinya: "Bacalah! Dengan nama Tuhanmu yang menciptakan, Dia telah menciptakan manusia dari segumpal darah, Bacalah, dan Tuhan-mulah yang Maha Pemurah, Yang mengajar (manusia) dengan perantaraan kalam, Dia mengajarkan kepada manusia apa yang tidak diketahuinya". (Q.S. Al'Alaq/96: 1-5).

Oleh sebab itu seruan risalah yang disampaikan kepada Muhammad ini merupakan seruan kenabian seperti yang disampaikan kepada nabi-nabi sebelumnya. Seruan dan risalah yang disampaikan oleh Muhammad, putra Arab itu adalah seruan kenabian seperti yang disampaikan oleh nabi-nabi Ibrani lainnya yang disebutkan dalam perjanjian lama (Hitti, 2008: 141-142). Inti ajarannya menegaskan bahwa Tuhan itu Esa, Dia Mahakuasa, dan Dia adalah pencipta alam raya. Dan bahwa akan datang hari pembalasan. Balasan pahala di surga menanti mereka yang melaksanakan perintah Tuhan, dan hukuman yang pedih di neraka menanti bagi orang yang mengabaikannya.

Maka oleh sebab itu, nampak jelas dengan turunnya ayat di gua hira ini, babak baru kehidupan Muḥammad telah dimulai. Beliau akan memikul tanggung jawab besar untuk menyampaikan risalah Tuhan kepada manusia terhitung mulai turunnya surah al-Alaq ayat 1-5 sampai akhir hayat beliau nantinya. Dan hal ini menjadi bahasan penting dalam kajian 
pemikiran pendidikan Islam sebagaimana yang ingin dibahas dalam pembahasan selanjutnya.

Sebelum memasuki bahasan selanjutnya kiranya perlu disebutkan orang-orang yang pertama kali menerima ajakan atau seruan Muḥammad SAW, mereka adalah Khadijah, kemudian disusul Ali, Abu Bakar, Usman, Abdur Rahman, Zaid, Zubair dan Thalhah. Dan pengikut Nabi semakin bertambah jumlahnya dalam 3-4 tahun masa dakwah, cercatat ada 40 orang yang beriman (Ali, 2003: 46).

\section{Perkembangan Pendidikan Islam Masa Nabi Muhammad SAW}

Sebelum berbicara lebih jauh tentang sejarah pemikiran pendidikan Islam pada awal perlu kiranya dikemukakan apa pendidikan Islam itu. Jika merujuk kepada pendapat para ahli tentunya dalam pemberian defenisi tentang pendidikan Islam satu sama lain memiliki perbedaan. Namun dalam kajian ini bukanlah itu menjadi persoalan utama. Berdasarkan hasil Seminar Pendidikan Islam di Indonesia yang dilaksanakan oleh Badan Kerjasama Perguruan Tinggi Islam Swasta (BKS-PTAIS) di Jakarta tahun 1979 secara sederhana, disana dimuat rumusan sebagai berikut: "Pengertian pendidikan Islam ialah usaha yang berlandaskan al-Islam untuk membantu manusia dalam mengembangkan dan mendewasakan kepribadiannya, baik jasmaniah maupun rohaniah untuk memikul tanggung jawab memenuhi tuntunan zamannya dan masa depannya" (Siddik, 2006: 23).

Dari definisi di atas tampak jelas bahwa pendidikan Islam adalah pendidikan yang berlandaskan Islam itu sendiri, itu artinya pendidikan Islam yang dimaksud tidak terlepas dari bagaimana Muhammad SAW mengaktualisasikan pendidikan sebagai seorang Nabi dan Rasul pembawa risalah Islam.

Pemikiran pendidikan pada masa awal itu tertuang dalam ayat-ayat alQur'an dan Sunnah Rasul yang mengajak manusia ke dalam ajaran Islam secara utuh dan terpadu meliputi beberapa aspek, yaitu aqidah, syari'ah, dan akhlak.

Pembentukan ketiga aspek ini "aqidah, syari'ah, dan akhlak" itu disajikan beliau sebagai pendidik agung secara berangsur-angsur bersamaan dengan berangsur-angsrunya al-Qur'an diturunkan kepada beliau (Dalimunthe, 1986: 26). Pelaksanaan pembinaan Pendidikan Islam pada zama Nabi tersebut dapat dibedakan menjadi dua tahap, baik dari segi waktu dan tempat penyelenggaraan, maupun dari segi isi dan materi pendidikannya, yaitu fase awal pembinaan pendidikan Islam, dimana mekah menjadi pusat kegiatannya, dan fase lanjutan (penyempurnaan) pembinaan pendidikan Islam dengan Madinah sebagai pusat kegiatannya (Zuhairini, 1992: 18).

\section{Pendidikan Islam Periode Makkah}

Sebelum Nabi Mụ̣ammad memulai tugasnya sebagai Rasul, yaitu melaksanakan pendidikan Islam terhadap umatnya, Allah telah mempersiapkannya untuk melaksanakan tugas tersebut secara sempurna, melalui pengalaman, pengenalan serta perannya dalam kehidupan masyarakat dan lingkungan budayanya. Dengan potensi fitrahnya, ia mampu secara sadar mengadakan penyesuaian diri dengan masyarakat lingkungannya (Zuhairini, 1992: 18), dan tidak terpengaruh dengan apa yang menjadi kebiasaan buruk orang pada saat itu. 
Pendidikan masa awal ini merupakan prototype (corak yang paling mendasar) yang terus menerus dikembangkan oleh umat Islam untuk kepentingan pendidikan pada zamannya. Pendidikan Islam mulai dilaksanakan Nabi Muḥammad setelah mendapat perintah dari Tuhan agar beliau menyeru kepada Allah, menyeru berarti mengajak, dan mengajak berarti mendidik. Allah SWT berfirman:

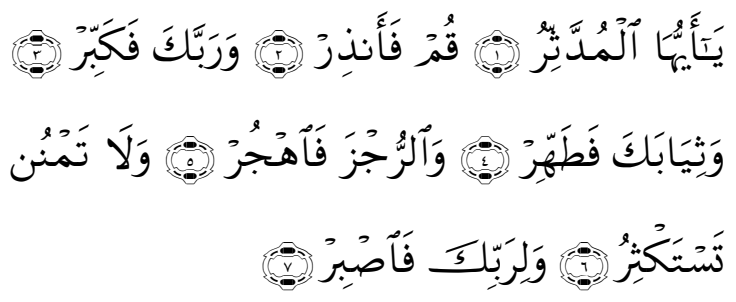

Artinya: "Hai orang yang berkemul (berselimut). Bangunlah, lalu berilah peringatan! Dan Tuhanmu agungkanlah! Dan pakaianmu bersihkanlah, Dan perbuatan dosa tinggalkanlah, Dan janganlah kamu memberi (dengan maksud) memperoleh (balasan) yang lebih banyak. Dan untuk (memenuhi perintah) Tuhanmu, bersabarlah." (QS. Al-Muddatsir, 74: 1-7).

Perintah dan petunjuk yang termuat dalam Q.S. 74:1-7 itu pertamatama tertuju kepada Muḥammad tentang apa yang harus ia lakukan, baik terhadap dirinya sendiri maupun terhadap umatnya. Itulah petunjuk awal bagi Rasul agar beliau memberikan peringatan kepada umatnya. Kemudian bahan/materi pendidikan diturunkan secara berangsur-angsur, sedikit demi sedikit. Setiap kali menerima wahyu segera ia sampaikan kepada umatnya secara diam-diam dan tersembunyi, dan diiringinya dengan penjelasanpenjelasan serta contoh-contoh begaimana pelaksanannya (Zuhairini, 1992: 21).

Disamping itu langkah selanjutnya yang ditempuh beliau adalah mengajak keluarganya terlebih dahulu. Hal ini terlihat sebagaimana riwayat menyatakan bahwa beliau pertama kali menyampaikan kabar itu kepada isterinya Khadijah (Asrohah, 1999: 12).

Sikap Nabi ini sangat logis mengingat kejadian yang beliau alami itu bukanlah peristiwa biasa, dan memang hal itu tidaklah mungkin bisa disampaikan kepada orang ramai dilingkungannya, mengingat masyarakat tempat ia tinggal adalah lingkungan yang sedang krisis moral. Sementara berita yang ia dapatkan sangatlah berkaitan dengan misi revolusi kepercayaan dan kebiasaan kaumnya pada saat itu. Maka dari itu beliau sebagai manusia dan memiliki isteri tentunya pertamakali mendiskusikannya dengan isterinya tersebut.

Kemudian diikuti oleh Ali bin Abi Thalib (anak pamannya) yang kemudian diangkat menjadi anak angkatnya, dan Zaid bin Haritsah seorang pembantu rumah tangganya, kemudian dijadikan pula anak angkat beliau. Setelah itu nabi Muḥammad mulai mengajak sahabat-sahabatnya dari kalangan Quraisy dengan ekstra hati-hati dan tidak sembarangan. Di antara mereka dari kalangan sahabat beliau yang terhitung lebih awal berjuang bersama Muḥammad di antaranya adalah Abu Bakar, Ustman bin Affan, Zubeir bin Awwam, Sa'ad bin Abi Waqqas, Abd al-Rahman bin 'Auf, Thallhah bin Ubaidillah, Abu Ubaidillah bin Jarrah, Arqam bin Abi al-Arqam, Fatimah binti Khattab bersama suaminya, Said bin Zaid, dan beberapa orang lainnya (Zuhairini, 1992: 12).

Dari beberapa orang yang telah beriman dan ikhlas ikut bersama Nabi Muḥammad, maka pendidikan bagi mereka diselenggarakan secara eksklusif di rumah Arqam bin Abi Arqam. Pemilihan rumah Arqam ini sebagai tempat penyelenggaraan 
pendidikan bagi para sahabat yang jumlahnya masih terbatas itu oleh Rasulullah disebabkan karena kesetiaan Arqam kepada Rasul dan Islam, juga letaknya sangat baik terlindung dari pandangan kaum Quraisy sehingga akan memberikan keamanan dan ketenangan kepada kaum muslimin yang sedang mengadakan kegaiatan dan pertemuan untuk menerima pelajaran yang disampaikan Rasulullah.

Adapun keadaan demikian itu berlangsung sampai lebih dari tiga tahun, sampai akhirnya turun petunjuk dan perintah dari Allah, agar Nabi memberikan pendidikan dan menyeru mereka secara terbuka. Allah SWT berfirman:

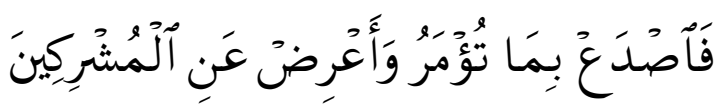

Artinya: "Maka sampaikanlah olehmu secara terang-terangan segala apa yang diperintahkan (kepadamu) dan berpalinglah dari orang-orang yang musyrik." (Q.S. Al-Hijr, 15: 94).

Dengan turunnya perintah tersebut, maka mulailah Muḥammad memberikan pengajaran kepada umatnya secara terbuka dan lebih meluas, bukan hanya dilingkungan kaum keluarga di kalangan penduduk Makkah, tetapi juga kepada penduduk di luar Makkah, terutama orang-orang yang memasuki Makkah baik dalam rangka ibadah maupun dagang. Dengan demikian, tantangan yang dihadapi oleh Nabi Muḥammad pun semakin terbuka.

Namun bila dicermati secara mendalam, dengan diizinkannya Muḥammad berdakwah secara terbuka maka berbagai tantangan dan propoganda pun mengalir deras berdatangan dari penduduk Makkah. Mereka pada saat itu pada umumnnya lebih cendurung untuk menolak dan melawan seruan nabi disebabkan oleh adanya anggapan bahwa kehadiran Muḥammad ditengah-tengah mereka akan membawa sisi negatif terhadap eksistensi kehidupan mereka pada saat itu. Adapun faktor-faktor yang mendorong kaum Quraisy menentang seruan Islam, di antaranya: (1) Persaingan kekuasaan; (2) Persamaan hak antara kasta bangsawan dan kasta hamba sahaya yang dilakukan oleh Rasulullah; (3) Takut dibangkit. Kaum Quraisy tidak dapat menerima: dan (4) agama Islam yang mengajarkan bahwa manusia akan hidup kembali sesudah mati; (5) Memperniagakan patung. Agama Islam melarang menyembah, memahat, dan menjual patung. Karena itu saudagar-saudagar patung memandang agama Islam sebagai penghalang rezeki dan akan menyebabkan perniagaan mereka mati dan lenyap (Soekarni \& Supardi, 1998: 37-38).

Namun keadaan itu tidak membuat Muhammad mundur dan menyerah, bahkan beliau semakin gigih dan bersungguh-sungguh untuk memberikan pendidikan dan pengajaran kepada mereka. Semuanya ia hadapi dengan penuh dengan kesabaran, dan dengan penuh keyakinan bahwa Allah akan selalu memberikan petunjuk dan pertolongan dalam menghadapi tantangan tersebut.

Pada periode Makkah ini pendidikan Islam dilaksanakan meliputi pendidikan tauhid dan pengajaran alQur'an. Atau ada juga yang menyebutnya dengan pendidikan aqidah dan ahklak. Tapi itu bukanlah menjadi persoalan sebab pada hakikatnya subtansi pendidikan yang ditanamkan oleh Rasul itu sudahlah termasuk di dalam kata-kata kunci tersebut. 
Pendidikan Tauhid

Sebagaimana dikemukakan bahwa dalam melaksanakan tugas kerasulannya nabi Muhammad SAW berhadapan dengan nilai-nilai warisan Ibrahim yang telah banyak menyimpang dari yang sebenarnya. Inti warisan tersebut adalah ajaran tauhid. Namun ajaran tersebut telah pudar dalam budaya masyarakat Arab Jahiliyah. Dan inilah inti sari pendidikan Islam pada periode Makkah ini (Zuhairini, 1992: 23-24).

Nabi Muhammad SAW

memperoleh kesadaran dan penghayatan yang mantap tentang ajaran tauhid, yang intisarinya adalah sebagaimana tercermin dalam surat alFatihah. Pokok-pokoknya adalah: (1) Bahwa adalah pencipta alam semesta yang sebenarnya, Dialah satu-satunya yang menguasai dan mengatur alam ini sedemikian rupa; (2) Bahwa Allah telah memberikan nikmat, memberikan segala keperluan bagi makhluknya, dan khusus kepada manusia; (3) Bahwa Allah adalah raja hari kemudian, dengan pengertian bahwa segala amal perbuatan manusia sewaktu di dunia ini akan diperhitungkan di sana; (4) Bahwa Allah adalah sesembahan yang sebenarnya dan yang satu-satunya; (5) Bahwa Allah adalah penolong yang sebenarnya, oleh karenanya hanya kepada-Nyalah manusia minta tolong, bukan kepada yang selainnya; dan (5) Bahwa Allah sebenarnya yang membimbing dan memberi petunjuk kepada manusia.

Intisari ajaran tauhid yang dibawa oleh nabi Muhammad SAW tersebut kemudian diajarkannya kepada umatnya. Karena pelaksanaan tauhid ternyata jelas-jelas bertentang dengan praktek kehidupan sehari-hari umat yang dihadapinya, maka wajar apabila banyak masyarakat pada zaman itu malah memusuhi beliau. Dan perlu juga diketahui bahwa itu juga sebabnya Nabi Muhammad dalam usahanya menyampaikan pengertian ajaran tauhid dilakukannya secara bertahap, dimulai dari keluarga terdekat secara sembunyi-sembunyi, baru kemudian terbuka kepada kalangan luas.

Pelaksanaan atau praktek pendidikan tauhid tersebut diberikan oleh Muhammad kepada umatnya dengan cara yang sangat bijaksana, dengan menuntun akal pikiran untuk mendapatkan dan menerima pengertian tauhid yang diajarkan, dan sekaligus beliau memberikan teladan dan contoh bagaimana pelaksanaannya.

\section{Pengajaran al-Qur'an}

Al-Qur'an merupakan intisari dan sumber pokok dari ajaran Islam yang disampaikan oleh Muhammad kepada umatnya. Tugas Muhammad disamping mengajarkan tauhid juga mengajarkan al-Qur'an kepada umatnya, agar secara utuh dan sempurna menjadi miliki umatnya, yang selanjutnya akan menjadi warisan berharga bagi umat muslimin sepanjang zaman.

Selanjutnya, ada beberapa faktor yang memungkinkan Nabi Muhammad mengajarkan al-Qur'an dengan baik dan sempurna. Masyarakat bangsa Arab masa itu dikenal sebagai masyarakat yang ummi yang pada umumnya tidak dapat membaca dan menulis, hanya beberapa orang saja yang dapat menulis dan membaca, memberi indikasi bahwa baca tulis belum membudaya dalam kehidupan mereka sehari-hari. Maka sangat pantas ketika turun wahyu pertama isinya adalah perintah membaca (iqra). Sehingga Nabi Muhammad dengan mudah mampu membaca situasi sekitarnya dan situasi masyarakat yang menjadi sasaran tugasnya. Itulah sebab kata iqra' dalam pengertiannya tidaklah hanya sebatas 
membaca seperti membaca yang dipahami pada umumnya. Sebagaimana M. Quraish Shihab menjelaskan Iqra' berarti bacalah, telitilah, dalamilah, ketahuilah ciri-ciri sesuatu, bacalah alam, bacalah tanda-tanda zaman, sejarah, diri sendiri, yang tertulis dan tidak tertulis. Alhasil objek perintah iqra' mencakup segala sesuatu yang dapat dijangkaunya (Shihab, 1996: 5-6). Maka oleh sebab itu Nabi Muhammad dalam memberikan pendidikan dan pengajaran terutama masalah al-Qur'an juga lebih mudah karena secara psikologis beliau sudah paham dengan karakter para sabahatnya. Walaupun ada beberapa orang dari mereka ada yang mampu membaca dan menulis tetapi bagi bangsa Arab pada masa itu lebih diunggulkan hafalannya, karena kegiatan tulis baca pada saat itu dianggap aib bagi mereka.

Pada saat itulah Nabi Muhammad memanfaatkan keberagaman yang dimiliki para sahabatnya. Kepada orang yang dapat menulis beliau menyuruh untuk menuliskan ayat-ayat yang turun dan juga beliau selalu memerintahkan kepada mereka untuk menghafalnya dengan baik. Dalam pengajaran ini tentunya Nabi Muhammad tidak lepas tangan, beliau terus mendampingi mereka dan ia juga mengevaluasi mereka pada saat-saat tertentu tentang apa yang sudah diajarkan kepada mereka.

\section{Pendidikan Islam Periode Madinah}

Karena di Makkah umat muslim selalu mendapat tantangan dari kaum Quraisy yang selalu mengganggu dakwah Islam, maka Rasulullah akhirnya memutuskan hijrah ke Madinah. Kedatangan Nabi Muhammad SAW bersama kaum muslim Makkah, disambut oleh penduduk Madinah dengan gembira dan penuh dengan rasa persaudaraan. Maka Islam mendapat lingkungan baru yang bebas dari ancaman para penguasa Quraisy Makkah (Shihab, 1996: 32).

Setelah sampai di Madinah usaha pertama yang dilakukan oleh Nabi adalah mendirikan Masjid sebagai benteng pertahanan rohani, tempat pertemuan, dan lembaga pendidikan. Di Masjid ini, Nabi melaksanakan shalat berjama'ah, membacakan al-Qur'an dan memberikan pengajaran Islam. Nabi juga mengadakan musyawarah yang berkenaan dengan kemasyarakatan dan politik Islam di Masjid ini.

Tujuan dan materi pendidikan Islam di Madinah ini semakin luas dibandingkan pendidikan Islam di Makkah. Seiring dengan berkembangnya masyarakat Islam dan semakin luas petunjuk-petunjuk Allah, semakin luas pula tujuan dan materi pendidikan yang dilaksanakan oleh Rasulullah. Pendidikan Islam tidak hanya diarahkan untuk membentuk pribadi kader Islam, tetapi juga membina aspek-aspek kemanusiaan sebagai hamba Allah untuk mengelola dan menjaga kesejahteraan alam semesta. Untuk itu, umat Islam dibekali dengan pendidikan tauhid, akhlak, ibadah, kehidupan sosial-kemasyarakatan dan keagamaan, ekonomi, kesehatan, bahkan kehidupan bernegara (Asrohah, 1999: 14-15).

Pada periode Makkah, ciri-ciri pokok pembinaan pendidikan Islam adalah pendidikan tauhid, sedangkan pada periode Madinah ini, ciri pokok pembinaan pendidikan Islam dapat dikatakan sebagai pendidikan sosial dan politik. Tetapi antara kedua ciri tersebut bukanlah merupakan dua hal yang bisa dipisahkan satu sama lain. Kalau pembinaan pendidikan Islam di Makkah titik beratnya adalah menanamkan nilai-nilai tauhid ke dalam 
jiwa setiap individu muslim, agar dari jiwa mereka terpancar sinar tauhid dan tercermin dalam perbuatan dan tingkah laku dalam kehidupan sehari-hari. Sedangkan pembinaan pendidikan Islam periode Madinah pada hakikatnya adalah merupakan kelanjutan dari pendidikan tauhid di Makkah, yaitu pembinaan di bidang pendidikan sosial dan politik agar dijiwa oleh ajaran tauhid, sehingga akhirnya tingkah laku sosial politiknya merupakan cermin dan pantulan sinar ajaran tauhid (Zuhairini, 1992: 33).

\section{Pembentukan dan Pembinaan Masyarakat Baru, Menuju Satu Kesatuan Sosial Politik}

Masalah pertama yang dihadapi Nabi Muhammad dan kaum Muhajirin adalah tempat tinggal. Untuk sementara para Muhajirin bisa menginap di rumah-rumah kaum Ansor, dan beliau sendiri memerlukan suatu tempat khusus di tengah-tengah umatnya sebagai pusat kegiatan, sekaligus sebagai lembaga kesatuan di antara kedua kelompok masyarakat yang mempunyai latar belakang kehidupan yang berbeda. Oleh sebab itulah rencana pembangunan Masjid oleh Nabi Muhammad menjadi sangat penting, maka pembangunan masjid pun menjadi salah satu usaha pertama yang dilakukan Rasulullah untuk bisa lebih mudah menyatukan kaum Muhajirin dan Anshor sebagaimana yang sudah dijelaskan di atas, dan dengan adanya Masjid ini Nabi Muhammad dibuatkan tempat khusus dan bagi kaum Muhajirin yang miskin yang tidak mampu membangun tempat tinggalnya sendiri, mereka ini kemudian disebut dengan ahl al-Suffah (Zuhairini, 1992: 35).

Maka masjid yang telah dirikan itulah pusat kegiatan Nabi Muhammad bersama kaum muslimin untuk secara bersama-sama membina masyarakat baru, masyarakat yang disinari oleh tauhid dan mencerminkan persatuan dan kesatuan umat. Di masjid itu pulalah beliau bermusyawarah mengenai berbagai urusan, mendirikan shalat berjamaah, membacakan alQur'an. Intinya keberadaan masjid itu merupakan pusat pendidikan dan pengajaran.

Setelah Nabi Muhammad SAW dapat mempersatukan kaum anshor dan muhajirin, maka beliau pun membangun strategi untuk mengantisipasi berbagai ancama dari orang Makkah dan orang Madinah yang diluar Islam seperti orang Nasrani dan Yahudi. Untuk itu mulailah beliau meletakkan dasar-dasar terbentuknya masyarakat yang bersatu padu secara intern (ke dalam), dan keluar diakui dan disegani oleh masyarakat lainnya sebagai satu kesatuan politik. Dasardasar tersebut adalah: (1) Nabi Muhammad SAW mengikis habis sisasisa permusuhan dan pertentangan antar suku, dengan jalan mengikuti tali persaudaraan di antara mereka. Misalkan Abu Bakar dipersaudarakan degnan Khairiyah bin Zubair, Umar dengan Itban bin Malik, Abu Ubaidah dengan Abdurrahman bin Auf serta Sa'at bin al-Rabi', dan sebagainya; (2) Untuk memenuhi kebutuhan hidup sehari-hari, Nabi Muhammad menganjurkan kepada Muhajirin untuk berusaha dan bekerja sesuai dengan kemampuan masing-masing seperti waktu di Makkah; (3) Untuk menjalin kerja sama dan saling tolong menolong dalam rangka membentuk tata kehidupan masyarakat yang adil dan makmur, turunlah ayat syariat zakat dan puasa, yang merupakan pendidikan bagi warga masyarakat dalam tanggung jawab sosial, baik secara materiel maupun moral; dan (4) Suatu 
kebijaksanaan yang sangat efektif dalam pembinaan dan pengembangan masyarakat baru di Madinah adalah disyariatkannya media komunikasi berdasarka wahyu, yaitu shalat jum'at berjamaah yang dilaksanakan berjamaah dan azan (Zuhairini, 1992: 36-37).

Kemudian Nabi Muhammad dalam rangka pembinaan kesatuan politik pertama-tama beliau membuat perjanjian kerjasama dengan orangorang Yahudi di Madinah. Perjanjian tersebut sekaligus berarti bahwa masyarakat baru yang terbentuk itu, telah mendapatkan pengakuan dari pihak Yahudi yang memang sudah lama merupakan suatu kekuatan politik yang berpengaruh di Madinah. Perjanjian tersebut dibuat secara tertulis, yang berisi tata hubungan timbal balik antara umat Islam dengan umat Yahudi Madinah, pengakuan atas agama dan harta benda mereka dengan syaratsyarat tertentu, yang kemudian perjanjian ini dikenal sebagai Konstitusi Madinah atau Piagam Madinah yang isinya sebanyak 39 point.

\section{Pendidikan Sosial Politik dan Kewarnegaraan}

Pelaksanaan atau praktek pendidikan sosial politik dan kewarganegaraan secara ringkas dapat dikemukakan sebagai berikut: Pertama, pendidikan Ukhwah (persaudaraan) antar kaum muslimin. Untuk mempersatukan masyarakat yang berbeda latar belakang maka Nabi Muhammad mengikat mereka dengan iman kepada Allah dan Rasul-Nya. Beliau meyakinkan kepada mereka bahwa "umat yang beriman itu bersaudara, karenanya perbaikilah hubungan persaudaraan". Adapun dasar pendidikan ukhwah ini terdapat dalam hadits beliau yang maknanya "Tidak beriman seseorang di antara kamu, sehingga mencintai saudaranya (sesama) sebagaimana mencintai dirinya sendiri". Dengan demikian, dalam kehidupan masyarakat kaum muslimin yang nampak bukan lagi hubungan antar keluarga (marga) tapi yang menonjol adalah hubungan persaudaraan, yakni Islamiyah.

Kedua, pendidikan kesejahteraan sosial. Untuk mengatasi masalah sosial terutama masalah kaum muhajirin yang belum mendapat pekerjaan Rasul memerintahkan kepada golongan Muhajirin yang belum mendapatkan perkerjaan agar bekerja bersama dengan saudara-saudara mereka yang telah dipersaudarakan sebelumnya (Ansor). Problem sosial berikutnya adalah behubungan dengan pengaturan dan penggunaan harta kekayaan yang dapat terkumpul dari usaha bersama antara kaum muhajirin dan ansor. Dimana sebagian mereka ada yang menjadi kaya dan ada yang masih membutuhkan bantuan, maka Nabi Muhammad pun megatur penggunaan harta kekayaan tersebut. Sehingga zakat dan sadaqah menjadi tulang punggung dalam menyalurkan dan mengatur harta kekayaan yang ada.

Ketiga, pendidikan kesejahteraan keluarga, kaum kerabat. Pendidikan kesejahteraan keluarga, kaum kerabat yang dimaksud ialah bahwa Nabi Muhammad SAW berusaha untuk memperbaiki keadaan yang kacau dengan memperkenalkan dan sekaligus menerapkan sistem kekeluargaan dan kekerabatan baru, yang berdasarkan takwa kepada Allah. Allah SWT berfirman:

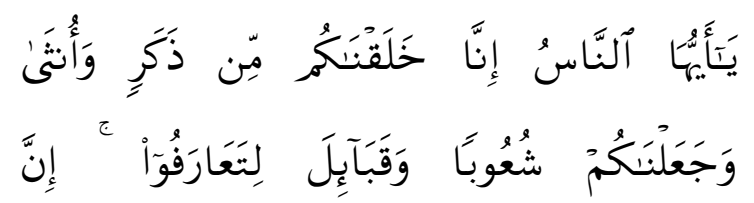




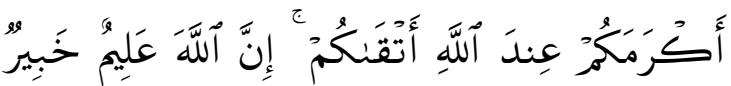

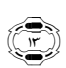

Artinya: "Hai manusia, Sesungguhnya kami menciptakan kamu dari seorang laki-laki dan seorang perempuan dan menjadikan kamu berbangsa-bangsa dan bersuku-suku supaya kamu saling kenal-mengenal. Sesungguhnya orang yang paling mulia diantara kamu disisi Allah ialah orang yang paling taqwa diantara kamu. Sesungguhnya Allah Maha mengetahui lagi Maha Mengenal. " (QS. Al-Hujarat, 49:13).

Ayat di atas menunjukan bahwa pertama-tama Islam mengakui adanya persamaan antara laki-laki dan perempuan sebagai individu-individu yang mempunyai hak dan kewajiban yang sama dalam kehidupan masyarakat. Pembentukan keluarga baru diatur dengan syarat dan cara tertentu, sehingga merupakan paduan hubungan suci yang mencerminkan rasa kasih sayang sesamanya.

Selain itu, Rasul juga dalam rangka membangun kesejahteraan keluarga, beliau tidak luput juga memperhatikan pendidikan bagi anak-anak sebagai penerus bagi keluarga, negara maupun agama Islam nantinya. Hal ini dapat dilihat bahwa beliau menginginkan agar anak dapat diberi bimbingan dan pendidikan supaya ia tumbuh dan berkembang, baik jasmani maupun rohaninya. Untuk pendidikan jasmani, misalnya beliau memerintahkan agar anak-anak diajarkan memanah dan naik kuda serta beranang. Dalam hal pendidikan kerohanian, diperkenalkan tentang Tuhan, dilatih untuk shalat pada umur 7 tahun dan melaksanakannya dengan baik pada umur 10 tahun, dibiasakan dengan adab sopan santun terhadap orangtua serta orang lain, dan sebagainya.

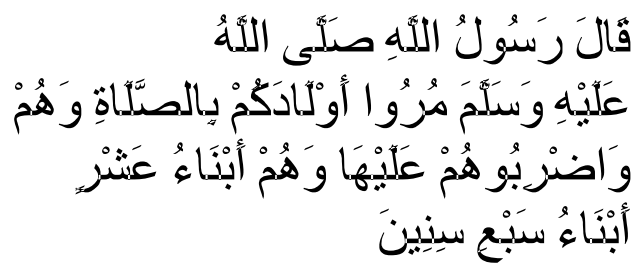

Artinya: "Nabi SAW bersabda:"Suruhlah anak-anak mengerjakan shalat, apabila telah berumur tujuh tahun, dan pukullah dia karena meninggalkannya apabila telah berumur sepuluh tahun (Arifin, dkk, 1992: 325)."

Oleh sebab itu dalam mempersiapkan pendidikan anak-anak yang kemuadian akan mampu menerima warisan Islam dan bertanggung jawab untuk mengemban tugas pengembangan dakwah Islam, maka sejak kecil mereka sudah diperintahkan untuk belajar membaca dan menulis, serta membaca dan menghafal ayat-ayat al-Qur'an (Zuhairini, 1992: 57). Sehingga pantaslah ketika terjadi perang badar, tawanan perang yang berasal dari suku Quraisy dibebaskan oleh Rasulullah dengan syarat bahwa tiap-tiap mereka mengajarkan baca tulis kepada 10 anakanak muslim (Ali, 2003: 130). Semenjak itu tulis baca dan kegiatan pendidikan lainnya berkembang dengan pesat di kalangan masyarakat Madinah. Semenjak itu pula Madinah bukan saja sebagai pusat pemerintahan Islam akan tetapi juga menjadi pusat pendidikan Islam.

Kemudian perlu dipertegas bahwa perintah tulis baca ini ternyata bukan saja ditujukan kepada anak laki-laki semata, tetapi juga kepada anak-anak perempuan. Oleh sebab itu tidak heran, bahwa kuttab pada saat itu telah diislamisasikan dari orang-orang Arab pra-Islam untuk menjadi lembaga pendidikan yang materinya adalah tulis baca itu sendiri. Walaupun pada awalnya pendidikan kuttab itu berlangsung di rumah para guru 
(mu'allim, mu'addib) atau dipekarangan sekitar masjid (Asari, 2007: 25).

Selain itu seiring dengan perkembangan Islam pada masa itu, di mana Islam telah tersebar diberbagai jazirah Arab, maka Nabi Muhammad mengatur pengiriman guru (mu'allim, mu'addib) untuk ditugaskan mengajarkan al-Qur'an kepada sukusuku terpencil (Ali, 2003: 130). Hal ini menunjukkan bahwa Nabi Muhammad SAW memiliki dedikasi yang tinggi terhadap pendidikan. Kepiawaian dan kebijaksanaan itulah kemudian modal para Khulafa al-Rasyidin untuk melanjutkan perjuangan Nabi Muhammad untuk mencerdaskan manusia dengan nilai-nilai tauhid. Maka terbuktilah tradisi membaca dan menulis dalam sejarahnya telah melahirkan ilmuan-ilmuan muslim yang tersohor dan bahkan tradisi itu masih dijiwai oleh umat sampai hari ini.

\section{SIMPULAN}

Dari penjelasan-penjelasan di atas, maka dapat ditarik kesimpulan antara lain bahwa pendidikan yang ditanamkan Nabi Muhammad SAW adalah pendidikan yang berorientasi kepada perubahan ideologi manusia secara mutlak. Pendidikan masa Rasul ini dapat dibagi menjadi dua tahap. Tahap pertama berlangsung di Makkah selama kurang lebih 13 tahun, dan periode Madinah sekitar 10 tahun. Materi pendidikan pada masa Rasul mencakup aqidah, syari'ah, dan ibadah.

Ciri-ciri khas pendidikan periode Makkah mencakup masalah tauhid (dalam arti luas), ibadah, serta sedikit tentang syari'ah. Sedangkan periode Madinah Rasul lebih cendurung melakukan pendidikan tentang syari'ah serta menumbuhkan perpolitikan yang luar biasa, untuk membentuk Madinah yang madani.
Pendidikan yang Rasulullah lakukan mempunyai strategi yang sangat bagus. Beliau segaja mendidik umatnya secara bertahap dengan berbagai pertimbangan dan perencanaan yang matang dan hal ini patut untuk diteladani oleh para pendidik di abad ini.

\section{DAFTAR RUJUKAN}

Al-Ghazali, Muhammad. tt. Fiqhus Sirah, terj. Abu Laila \& Muhammad Tohir, Bandung: Al-Ma'arif.

Ali, K., 2003. Sejarah Islam "Tarikh Pramodern". Jakarta: Raja Grafindo Persada.

Arifin, Bey, dkk., 1992. Terjemahan Sunan Abi Daud. Semarang: AsySyifa'.

Asari, Hasan. 2007. Menyingkap Zaman Keemasan Islam, Bandung: Cita Pustaka Media.

Asrohah, Hanun. 1999. Sejarah Pendidikan Islam. Jakarta: Logos Wacana Ilmu.

Dalimunthe, Fakrur Razi. 1986. Sejarah Pendidikan Islam. Medan: Rimbow.

Hitti, Philip K., 2008. History of The Arabs. Jakarta: Serambi Ilmu Semesta.

Shihab. M. Quraish. 1996. Wawasan alQur'an "Tafsir Maudhu'i Atas Pelbagai Persoalan Umat. Bandung: Mizan.

Siddik, Dja'far. 2006. Ilmu Pendidikan Islam. Bandung: Cita Pustaka Media.

Supardi, Ahmad dan Soekarno. 1998. Sejarah dan Filsafat Pendidikan Islam. Bandung: Angkasa.

Yatim, Badri. 2004. Sejarah Peradaban Islam, Dirasah Islamiyah II. Jakarta: Raja Grafindo Persada.

Zuhairini, dkk., 1992. Sejarah Pendidikan Islam. Jakarta: Bumi Aksara. 